\title{
СОЦИАЛЬНАЯ СТОРОНА КОНЦЕПТА 'ЗРИТЕЛЬНОЕ ВОСПРИЯТИЕ' В РУССКОЙ И ПОЛЬСКОЙ ЯЗЫКОВЫХ КАРТИНАХ МИРА (НА МАТЕРИАЛЕ ГЛАГОЛОВ ЗРИТЕЛЬНОГО ВОСПРИЯТИЯ)
}

\author{
THE SOCIAL DIMENSION OF THE CONCEPT OF ‘VISUAL PERCEPTION' \\ IN THE RUSSIAN AND POLISH LINGUISTIC PICTURE OF THE WORLD \\ (BASED ON VISUAL PERCEPTION VERBS)
}

\author{
DARIA SŁUPIANEK-TAJNERT
}

\begin{abstract}
The article discusses the social dimension of the concept of VISUAL PERCEPTION in Russian and Polish based on visual perception verbs. Similarities and discrepancies in creating the concept in both languages are indicated. The analysis takes into consideration the anthropocentric factor in forming the concept.

Daria Słupianek-Tajnert, Uniwersytet im. Adama Mickiewicza w Poznaniu, Poznań - Polska, ds@amu.edu.pl

В философии мышление всегда осмысливалось посредством видения... Господство зрения настолько глубоко укоренено в греческой речи и как результат в нашем концептуальном языке, что мы редко над этим задумываемся1.
\end{abstract}

Процитированные слова Ханны Арендт позволяют осознать огромную роль чувства зрительного восприятия прежде всего для интеллектуальной деятельности и, кроме того, побуждают задуматься над совокупностью значения зрительной перцепции для человеческого существования.

Концепт ЗРИТЕЛЬНОЕ ВОСПРИЯТИЕ (ЗВ) обЛадает в язЫковой картине мира (ЯКМ) русских и поляков богатой репрезентацией в рамках разных частеречных категорий. В данной статье мы ограничиваемся глагольной репрезентацией экземплификационного материала, результаты анализа которого должны продемонстрировать социальную сторону названного выше концепта в русском и польском языках, а бо-

1 Х. А р е н д т, Истоки тоталитаризма, Москва 1995, цит. по: А.Ю. 3 е н к о в а, Визуальные исследования как интегральная область социально-гуманитарного знания, [в:] электронный ресурс: http://www.ifp.uran.ru/files/publ/eshegodnik/2004/9.pdf (16.08.2015). 
лее детально говоря - сопоставить видение с социальной сферой с учетом сходств и различий в обоих языках.

Группа глаголов зрительного восприятия репрезентирована большим количеством лексических единиц, но материалом для анализа послужили только те глаголы, которые в состоянии выражать социальные значения и для которых значение зрительной перцепции является основным (что устанавливается на основании толковых словарей): $b u-$ деть, видеться (увидеться), глядеть, досматривать, заглядывать, заметить, наблюдать, надзирать, обследовать, осмотреть, присматривать, просмотретъ, следить, смотреть (посмотреть), lustrować, obejrzeć (ogladać), ogladać się, popatrzeć, widzieć, widzieć się, widywać się, zaglądać, zagladnać, zapatrzyć się, zauważać, zerkać, zobaczyć, zobaczyć się.

Неслучайно мы сопоставляем здесь видение с человеком как социальной личностью. Отражение концепта на языковом уровне насквозь пронизано антропоцентрическим фактором, а лексика - это ведь не точное отражение действительности, а скорее отражение способа, как эта действительность воспринимается.

Определяя личность как социальную, мы понимаем ее как личность, живущую в обществе, вступающую разными путями в интеракцию с другими его членами. Основным средством обмена информацией является язык, но взаимопонимание и взаимодействие достигаются также другими способами. Нельзя не учесть важность языка жестов, понимание которого осуществляется зрительным каналом. Нельзя упустить из виду важность взора для получения и передачи информации. Это вытекает из факта, что интеракция лицом к лицу является основной для человека. В свете сказанного зрение становится существенной составляющей для межличностных отношений. Эта взаимосвязь видения и коммуникации находит отражение на языковом уровне и ее можно рассматривать в следующих аспектах: а) межличностные отношения (встреча, свидание); б) выражение замечания; в) подражание кому-чему-либо; г) возможность рассчитывать на кого-л. и возложение на кого-л. надежд; д) контроль, забота, присмотр; е) привыкание к новым условиям существования; ж) коммуникация зрителя, наблюдателя с автором произведения.

1. Уже глаголы buдеть и widzié́, составляющие ядро номинативного поля концепта 3В, обладают интересующим нас социальным измерением. Предлагаем начать со значений 'встречаться, иметь свидание с кем-л.' / 'spotykać kogoś'. Их реализацию мы находим в следующих предложениях:

Кого вы видите на площадках, каких молодых ююдей привлекает эта игра? (НКРЯ²). А потом концерт кончился, и вы её никогда больше не видели (НКРЯ).

${ }^{2}$ Национальныи корпус русского языка (НКРЯ), [в:] электронный ресурс: www.ruscorpora.ru (20.08.2015). 
Omawiana jest sprawa dalekiej kuzynki. On nigdy jej nie widział (KJP3).

Jeden $z$ nich [...] znat Beatę S. Twierdzit, iż widziat ja trzy razy w życiu wokolicznościach handlowych, a raz na prywatce (KJP).

В данном значении глаголов видеть и widzieć зафиксирована межчеловеческая установка, касающаяся правил общения, отношений между людьми. Подчеркивается существенность зрительного контакта для каркаса общения. Важность видения для социальной обстановки актуализируется также в формулах речевого этикета типа: pad (bac) buдеть; буду рад (bac) buдеть; miło mi (będzie) pana/pania widzié́, употребляемых как учтивое приветствие при встрече со знакомыми и при приглашении в гости, или же могу я, можно видеть кого-л.?; czy mógłbym się widzié́ z kimś?, употребляемых как просьба допустить к кому-л.

Встреча фиксируется также в употреблении возвратных глаголов: видеться, увидеться, widzieć się, zobaczyć się, widywać się, напр.:

Я с ней вижусь периодически, раза два в месяи (НКРЯ).

Или ещё одно странное чувство: бывает, нам кажется, что этого человека мы знаем давно, хотя видимся с ним впервые (НКРЯ).

И тогда мы сможем возобновить наши контакты и даже, может быть, увидеться (НКРЯ).

В первый раз они увиделись ещё в тюремной больнице [...] (НКРЯ).

Witaliśmy się tak, jakbyśmy nie widzieli się już z dziesięć lat (KJP).

Raz w miesiacu jadę do Tokio, przyjmuje mnie pierwszy sekretarz, widze się z rodakami, nie mamy sobie za dużo do powiedzenia (KJP).

Równocześnie jednak widują się co dzień, wspólnie wychodza na miasto (KJP).

Widujemy się rzadko, prawie zawsze przy okazji zawodowych obowiazków [...] (KJP).

Gdybyśs się tu przypadkiem wybierata kiedyś, to chętnie bym się z Toba zobaczył (KJP).

Niech się nie wygtupiaja, ja pracuję, zobacze się z nimi wieczorem [...] (KJP).

Кратковременный визит у кого-либо запечатлевают глаголы загляdыbamь / zagladać, zaglądnać:

Иногда я, приученный к свободе и общительности, заглядывал к тёте Кате, вежливо постучав в дверь и испросив разрешения воитти - этому она научила меня с первых дней нашей жизни здесь (НКРЯ).

Dzień po powodzi wójt przyjechat do wsi, posiedział u sottysa dwie godziny, do nas nawet nie chciał zaglądnąć [...] (KJP).

Oczywiście nie zagladałem nawet do Ciebie, należała Ci się samotność pilnego stypendysty (KJP).

Значением 'встречать' обладает также русский глагол наблюдать (наблюдать 'видеть, замечать, встречать') (ГР $)$, напр.:

Вы наблюдали когда-нибудь альбиносов? (ГР).

${ }^{3}$ Korpus Jezyka Polskiego Wydawnictwa Naukowego PWN (KJP), [в:] электронный ресурс: http://korpus.pwn.pl (18.08.2015).

4 Справочно-информационный портал Грамота.ру (ГР), [в:] электронный реcypc: http://gramota.ru/ (20.08.2015). 
Следует заметить, что непосредственный польский эквивалент глагола наблюдать - obserwować - не имеет обсуждаемого значения 'встречать'.

2. В двух очередных глаголах: заметить / zauważyć примарное значение зрительной перцепции послужило средством выражения замечания. Замечая что-л., принимая участие в обмене мнениями, мыслями, тоже имеем дело с коммуникацией, это очередное измерение обсуждаемой нами связи видения с человеком как социальным существом. Замечания являются одной из составляющих контраргументации, словесных поединков, они могут быть обусловлены желанием оставить за собой последнее слово. Кроме того, психологи говорят о замечаниях, что это „сигналы интереса собеседника, его озабоченности обсуждаемым вопросом и/или просто - знаки внимания к личности говорящего и умения слушать" 5 . В контексте сказанного следует отнести замечания не к барьерам коммуникации, а скорее к ее катализаторам, даже помощникам ${ }^{6}$. То, как мы оцениваем замечания с точки зрения процесса протекания общения, зависит, между прочим, от характера говорящих, от их отношения к словесным репликам собеседника. Тем не менее замечания - это важная составная коммуникации, и они могут быть выражены глаголами, принадлежащими примарно к группе глаголов зрительного восприятия, напр.:

Ведь заметим, нам это только на руку: зная свои промахи и ошибки, легче выправить курс, наполнить газету содержанием, отвечающим вкусам самых разнообразных читателей (НКРЯ).

„Мы ведь нъю-йоркцы, и нас такими вещзами не удивишь", - заметил он (НКРЯ). Fizycy - jak zauważa w "Fantastyce i futurologii” Stanistaw Lem - gdyby czytali niektóre prace krytycznoliterackie, mieliby niemało powodów do wesołości (KJP).

Jak zauważa jednak dziennikarz, ta samocenzura jest dość subtelna, bo hongkoński czytelnik, przyzwyczajony do miarodajnych opinii, szybko wyczuje fałsz (KJP).

3. Следующие группы значений, которые, на наш взгляд, можно обсуждать через призму связи видения с социальным фактором, создают глаголы, обозначающие подражание кому-либо, следование какому-либо образцу, примеру. Процесс социализации личности предусматривает, между прочим, то, что индивид учится соответствующим навыкам с помощью других людей, он получает разного вида указания, относящиеся к поведению, основные знания о мире, благодаря чему человеку легче функционировать и развиваться. Так понимаемый социальный аспект находит отражение в значениях глаголов гляdemb, zapatrywać się (zapatrzyć się):

5 В. С е р г е е ч е в а, Словесное каратэ. Стратегия и тактика общения, Санкт-Петербург 2002, с. 10 .

6 Там же. 
Глядя на тебя, все зайцы такими станут (НКРЯ).

На него глядеть нечего, он не был ни в моей, ни в вашей шкуре (НКРЯ).

Polacy prowadzili w tym secie jeszcze 9:8, ale potem zapatrzyli się na Marcina Nowaka, który w catym meczu zepsut chyba więcej serwów niż ich prawidtowo wykonat (KJP). Skąd ty tak zmądrzałeś nagle? - Na Jampolskiego się zapatrzyłem (KJP).

4. В рамках связи видения с человеком как социальной личностью следует еще вспомнить о трех глаголах, а именно oglądać się, patrzeć, oглядываться в следующих значениях:

oglądać się 'liczyć na kogoś lub na coś': Nie ogląaj się na nikogo, licz tylko na siebie $\left(\mathrm{SWJP}^{7}\right)$;

patrzeć 'zabiegać o coś, dbać o coś': Patrzeć ciagle na pomoc rodziców. Patrzał tylko, żeby objąć stanowisko (SWJP8);

оглядываться 'поступать осторожно, с опаской; глядя на других': Поступай, как знаешь, на меня не оглядывайся. [...] Любить - так уж не оглядываясь! (без оглядки, не думая, не рассуждая) (ГР);

Tak liczna rodzinę trzeba koniecznie rozdzielić, bo tak jeden ogląda sie na drugiego i pozostaja bierni... (KJP);

Polscy biznesmeni powinni sami zdobywać ważne dla przebiegu negocjacji informacje, nie oglądajac się na innych (KJP);

Надо решать самим, оглядываться не на кого (ГР);

Он должен оглядываться на тех, от кого зависит его будущая судьба (НКРЯ).

Если мы на кого-либо рассчитываем, возлагаем на кого-либо надежды, тогда активизируется, конечно, межличностный фактор, принадлежащий социальной сфере.

5. Сосредоточиваясь на вопросе функционирования глаголов зрительной перцепции и их связи с социальной стороной жизни человека, следует учесть также те значения глаголов, которые фиксируют заботу, присмотр, контроль над кем-чем-либо.

Социализация - это конкретные виды взаимодействия индивида со средой. Некоторые этапы развития человека требуют присмотра (речь идет прежде всего о детском возрасте, но это, конечно, не единственный пример). Бывает, что мы хотим стоять на страже нравственности, порядка, закона, а необходимым условием, чтобы это осуществить, является, несомненно, обозначение и соблюдение определенных границ.

Обсуждаемый вопрос связи концепта 3В с социальным фактором предлагаем условно определить как контрольный аспект. Этот контроль обладает, однако, разносторонним измерением - от профессионального до личного.

7 Stownik wspótczesnego języka polskiego (SWJP), red. B. Dunaj, Warszawa 1996, s. 673.

8 Там же, с. 728. 
С профессиональным контролем (который понимаем как выполнение своих обязанностей на работе) сталкиваемся прежде всего в употреблении глагола досматривать:

Оба эти соглашения дают право американским кораблям досматривать в международных водах тысячи коммерческих судов в поисках оружия массового поражения, которое могут использовать на море террористические организации (НКРЯ); В октябре на парижской неделе pret-á-porter при входе в Карусель Лувра впервые досматривали вещи приглашённых - как в аэропорту (НКРЯ).

Досмотр, который отражен в процитированных предложениях, не вызывает противоречий, если речь идет о целенаправленности его совершения, он должен гарантировать безопасность экипажа самолета или посещающих музей людей. Обсуждаемый контроль проходит, как можно предполагать, при употреблении какого-то специального оборудования, но он не мог бы быть успешно проведен без участия зрения. Поэтому не удивляет факт, что именно у глагола зрительной перцепции появилось значение, связанное с проверкой, контролем.

Здесь следует также упомянуть глагол присматривать:

Чтобы поездам и пассажирам было хорошо, за рельсами присматривают монтёры пути - люди в оранжевых жилетах [...] (НКРЯ).

Представленная в процитированном предложении ситуация относится, несомненно, к контролю в профессиональной сфере; контроль, осуществляемый монтерами пути, принадлежит к их профессиональным обязанностям.

Обращают на себя внимание также контекстные употребления таких русских глаголов, как: наблюдать, надзирать, обследовать, осмотреть, следить, смотреть:

Также пристально СП будет наблюдать за деятельностью госкорпораций и проектов, реализуемых на принципах государственно-частного партнёрства (НКРЯ).

Но при этом прокурор области, обязанный по должности надзирать за работой милиции, оказывается в тройке лучших руководителей округа (НКРЯ).

В декабре 1952 года лабораторию Знойко обследовала комиссия под руководством одного из заместителей Курчатова (НКРЯ).

Но его [самолёт] периодически осматривали, проверяли, и специалисты [...] давали разрешение на продолжение полётов (НКРЯ).

По мнению некоторых авторов, прокуратура следит за исполнением не только законов, но и подзаконных актов [...] (НКРЯ).

Полковник Снивин молчал, похлопывая коня рукой $b$ перчатке с раструбом, смотрел за порядком, чтобы никто ничего не спутал (НКРЯ).

Приведенные предложения запечатлевают разные профессиональные обязанности, напр.: наблюдение за деятельностью госкорпораций, надзор за работой милиции, обследование лаборатории, осмотр самолета. 
Все перечисленные действия являются здесь профессионально обусловленными, они связаны со спецификой выполняемой работы.

В польском языке в рассматриваемом нами контрольном аспекте доминировали бы глаголы nadzorować, sprawdzać, kontrolować, однако они не являются сугубо глаголами зрительного восприятия (хотя с семантической точки зрения обнаруживается связь со зрением). Русская ЯКМ намного богаче фиксирует связь концепта ЗВ с контролем в профессиональной сфере.

Мы считаем, однако, что если иметь в виду польские глаголы зрительной перцепции и их употребление в контексте профессионального контроля, то надо назвать здесь глагол lustrować (основное значение: 'przyglądać się bacznie, krytycznie komuś lub czemuś') (USJP) в следующих значениях:

lustrować '2. urz. dokonywać lustracji, przeglądu, kontrolować, sprawdzać stan czegoś':

Dowódca lustrowat oddziat. Lustrować teren robót. 3. polit. 'sprawdzać przeszłość kandydatów na stanowiska państwowe': Lustrować czyjeś akta (USJP).

Zdarzenie rzeczywiście paradoksalne - oto lustruja przysztego szefa Instytutu Pamięci Narodowej, który czegoś nie pamięta (KJP).

В рамки профессиональной сферы вписывается также осмотр, совершаемый врачом, т. е. контроль состояния здоровья. Здесь надо учесть глаголы обследовать, осмотреть и смотреть, напр.:

Мы вас госпитализируем, обследуем, и всё будет хорошо (НКРЯ).

Все семейные врачи теперь обязаны не только обследовать и лечить больных, но и заносить сведения о них в национальный регистр [...] (НКРЯ).

Врач осмотрел его ноги и определил болезнь (НКРЯ).

Врач осмотрит пациента, сделает необходимые исследования, при необходимости даст ему обезболивающее [...] (НКРЯ).

Врач смотрел на меня три раза, но ничего не обнаружил (ГР).

Фактический материал вновь ограничен здесь в преобладающей части русскими примерами. Польский глагол badać не является глаголом зрительной перцепции в своем основном значении (badać 'dokładnie, gruntownie poznawać coś za pomocą analizy naukowej') (USJP), намек на зрительную перцепцию содержится в одном из его дальнейших значений, т. е. badać 'poddawać kogoś, coś oględzinom lekarskim, oceniać stan zdrowia za pomocą odpowiednich metod' (USJP), где существительное oględziny соединяет называемое глаголом badać действие со зритель-

${ }_{9}$ Uniwersalny stownik jezyka polskiego (USJP), red. S. Dubisz, [CD-ROM] wersja 1.0, 2004, Wydawnictwo Naukowe PWN, Warszawa. 
ной перцепцией. Значение контроля состояния здоровья появляется в предложениях типа:

Lekarz obejrzat / ogladał moje gardto, zajrzał mi do gardta, popatrzyt / zerkną / spojrzał na moje gardto, ogladat gtowe pacjenta.

Для выделенных здесь глаголов упомянутое значение не является основным, ибо в обсуждаемом контексте медицинского осмотра в польском языке доминирует глагол badać.

Как мы уже подчеркивали, контрольный аспект - это не только профессиональная сфера, но и личная. Так, глагол досматривать, который упоминался выше, может употребляться также в рамках личной сферы жизни. Речь идет о следующем значении данного глагола:

досматривать 'присмотреть за кем-, чем-либо, ухаживая, заботясь и т. п.': Досматривать за домом, за детьми, за хозяйством (ГР).

Процитированное значение обладает стилистической пометой разг. Удивляет факт, что НКРЯ не фиксирует ни одного употребления глагола досматривать в этом значении. Оно является, как можно предполагать, фоновым. Тем не менее в интернет-ресурсах мы нашли следующий пример:

Извините, а вы что, рожаете детей только для того, чтобы они досматривали Вас $b$ старости? 10

Как можно полагать, глагол досматривать доминирует скорее в области профессионального контроля. Зато очень большой частотностью употребления в контексте личного, семейного контроля обладает глагол присмотреть (присматривать):

Меня не взяли, оставив присматривать за малымами (НКРЯ).

Раз В неделю я приходил проверить, Все ли $b$ порядке. За домом присматривали соседи (НКРЯ).

Уже в сентябре она задешево сняла дачу на взморье, но сама туда не поехала, присматривать за дядей поручено было мне и Наталье (НКРЯ).

Однажды фермер поехал на ярмарку, оставив жену дома присматривать за хозяйством (НКРЯ).

Итак, личный контроль сводится здесь к присмотру за малышами, дядей или за хозяйством, к оказанию дружеской услуги соседу (присмотр за его домом).

Следующие глаголы, которых нельзя не учесть в этой части работы, - это глаголы глядеть, приглядеть, следить, углядеть, усмотреть:

10 Электронный ресурс: http://news.tut.by/health/345002.html (08.05.2014). 
Может, заболел, а и приглядеть за ним некому (НКРЯ).

Строгий устав её большого семейства, скорее всё-таки восточного, соблюдался всеми детьми. Особенно приглядывал за порядком старший брат (НКРЯ).

Мэри бралась за любую работу, позволяюшую ей следить за детьми и успевать заниматься домом (НКРЯ).

Царь Николай, нехороший такой, не углядел за А.С. Пушкиным, не запретил стреıять Дантесу (НКРЯ).

Это его вина, вина Артема, он не усмотрел за мальчишкой, согласился играть В его странные игры с трубами [...] (НКРЯ).

Забота, присмотр в некой степени обнаруживаются в следующих разговорных употреблениях польских глаголов зрительной перцепции:

Spójrz / zerknij / popatrz przez chwilę na dziecko, zaraz wrócę.

Эти употребления связаны с значением 'sprawdzić oglądaniem, obejrzeć, przyjrzeć się' (USJP), которое появляется в USJP в толковании глагола popatrzé́, но это только общее указание на контроль. Непосредственная связь зрительной перцепции с заботой, уходом более ярко отражается в дефинициях русских глаголов. Следует добавить, что семантический компонент 'забота' можно заметить в толковании глаголов dogladnać - dogladać 'zaopiekować się, (opiekować się) kimś lub czymś, otoczyć (otaczać) kogoś troskliwą opieką, sumiennie zająć się (zajmować się) czymś': Doglądać chorego. Doglądać gospodarstwa, kwiatów, zwierzą domowych (USJP), но в современном польском языке этот глагол не обладает значением зрительной перцепции, поэтому он здесь не учитывается. Связь со зрительным восприятием проявляется только в этимологии. В этимологическом словаре В. Борыся помещена информация о том, что в XVI веке глагол dogląać употреблялся также в собственно перцептивном значении 'patrzeć, zwracać uwagę, obserwować, przyglądać się; wglądać, wnikać'11.

6. Функционирование человека в обществе предусматривает также адаптацию к новым условиям существования, что фиксируется в значении таких глаголов зрительной перцепции, как: оглядеться, осмотретьcя, rozgladnać się, rozejrzeć się. Подтверждение мы находим в предложениях:

Прошла неделя, бабушка уехала, и я мог уже несколько оглядеться $b$ новых условиях школьной жизни (НКРЯ).

Она огляделась в новом коллективе довольно скоро (ГР).

Чтобы тебе здесь оглядеться, время надо (ГР).

Ко мне может устроиться ююбой. Сначала я даю ему неделю -осмотреться (НКРЯ).

Осмотрюсъ в столице - сразу напишу тебе (ГР).

Rozglądną się w nowej sytuacji (SWJP).

11 W. B o r y ś, Słownik etymologiczny języka polskiego, Kraków 2005, c. 116. 
Упомянутые выше глаголы оглядеться, осмотреться, rozgladnać się не слишком часто употребляются в приведенных значениях привыкания к определенным условиям, тем не менее их нельзя упустить из виду в контексте обсуждаемой проблематики.

7. Последний вопрос - это коммуникация зрителя, наблюдателя с определенным автором (напр.: живописцем, режиссером, постановщиком театральной пьесы, фильма, фотографом и т. п.). Здесь мы имеем в виду такие глаголы зрительной перцепции, как: просмотреть, глядеть, видеть, смотреть (посмотреть), оbejrzeć, ogladać, widzieć. Приведем ряд случаев их употребления:

С.Т. Морозов просмотрел спектакль и решил, что нашему театру надо помочь (НКРЯ).

Мы собрались и несколько раз просмотрели фильм (НКРЯ).

Najprawdopodobniej zapoznat się z dotychczas zebranymi informacjami o zjawach, obejrzał nagrania, przeczytat ekspertyzy i raporty (KJP).

Айда на выставку картины глядеть (ГР).

Звал к себе глядеть колекиию (ГР).

Да нет, не волнуйся - и Юра, и Алесь впервые видели спектакль, они в восторге [...] (НКРЯ).

Czy pan widziat ten film, czy pan widziat ten wywiad? (KJP).

Kto nie widział jeszcze w życiu filmu islandzkiego, ma szansę zaczać od dzieła naprawdę wyjątkowego (KJP).

А меня отправили смотреть выставку "Человек и тюрьма", которую я давно избегала, поскольку не Рембрандт же это, не малые голандиы и не франиузские реалисты (НКРЯ).

В приведенных нами контекстах появляются, например, такие объекты зрительного восприятия, как: фильм, спектакль, выставка, коллекциия, картины, wywiad, film, spektakl. Это лишь примерные существительные, которые могут появиться в обсуждаемом нами социальном аспекте. Самым важным для нас является, однако, замечание, что эти объекты предназначены, главным образом, сугубо для зрительного восприятия. Чтобы осознать их суть и оказаться, как субъект зрительного восприятия, участником диалога (субъектом, воспринимающим адресованное ему сообщение) с автором произведения, необходимым является именно чувство зрительной перцепции, которая выражена с интересующей нас точки зрения глагольной репрезентацией.

В контексте видения и коммуникации, как части социальных рамок жизни личности, показательным является факт, что в некоторых областях зрение является по сути единственным орудием получения информации. Например, в случае изобразительных искусств обратная связь осуществляется лишь сквозь призму зрительного плана, являющегося каналом общения между художником и реципиентами данно- 
го произведения искусства. Подобным образом дело обстоит хотя бы с кинематографией, но в этом случае, конечно, визуальную сферу сопровождает слуховая. Это касается и других областей широко понимаемой массовой культуры, источником которой является, например, телевидение.

Отражение визуальности культуры в употреблении глаголов зрительного восприятия как в русском, так и в польском языках обогащает, несомненно, концепт ЗВ, соединяя витальные ценности (умение видеть) и обусловленные витальными ценностями эстетические ценности.

Нельзя не признать, что фотографии, изображения, фильмы - это воплощение какой-то точки зрения ${ }^{12}$, это конечный результат аналитического труда автора, представление его позиции, интеллектуальной работы ${ }^{13}$. Однако такая же интеллектуальная работа ожидается со стороны аудитории, требуется активный подход зрителя к воспринимаемому визуальному артефакту, который может отличаться, например, смысловой полифонией.

Существуют разные, часто совсем противоположные точки зрения на применение упомянутого выше активного подхода к зрительно воспринимаемым объектам. Есть авторы, которые скептически относятся к интеллектуальной активности зрителя ${ }^{14}$. В других работах находим намного большую веру в его интеллектуальную активность. С. Тиссерон пишет:

Nie można przeciwstawiać świata obrazów - rzekomo pogrążającego człowieka w chaosie, światu języka, który pomaga się z niego wydobyć, ani tym bardziej utrzymywać, że obrazy zubażają wyobraźnię, a język rozwija. Zawsze najważniejsza jest postawa odbiorcy - widza, czytelnika, słuchacza - wobec tego, co ogląda lub słyszy ${ }^{15}$.

Здесь самым существенным является отношение зрителя к тому, что он воспринимает, его желание осознанного накопления информации, содержащейся в воспринимаемом при помощи зрения объекте.

Подытоживая сказанное, следует подчеркнуть, что в ЯКМ русских и поляков проявление связи зрительной перцепции с человеком как социальной личностью в основном совпадает, однако можно заметить

\footnotetext{
12 Sposoby widzenia. Na podstawie cyklu programów telewizyjnych BBC Johna Bergera, Poznań 1997, c. 10.

13 П.В. Р о м а н о в, Е.Р. Я р с к а я - С м и р н о в а, „Антропологический форум", Санкт-Петербург 2007, № 7, с. 86.

14 См., напр., G. S a r t o r i, Homo videns. Telewizja i postmyślenie, Warszawa 2007.

${ }^{15} \mathrm{~S}$. T i s s e r o n, Dziecko w świecie obrazów, 2006, [в:] электронный ресурс: http://www.civilia.pl/art,112,moc-obrazu-wedlug-sergei-39-a-tisserona (02.07.2015).
} 
различия в степени проявления некоторых признаков. В русском языке в намного большей степени, чем в польском, проявляется связь зрительной перцепции с контрольным аспектом. Связь с привыканием к новым условиям существования также незначительно заметнее в ЯКМ русских. Остальные обсуждаемые нами связи проявляются, на наш взгляд, в относительно одинаковой степени.

\section{Библиография}

А р е н д т Х., Истоки тоталитаризма, Москва 1995, цит. по: А.Ю. 3 е н к о в а, Визуальные исследования как интегральная область соииально-гуманитарного знания, [в:] электронный ресурс: http:// www.ifp.uran.ru/files/publ/eshegodnik/2004/9.pdf (16.08.2015).

Национальный корпус русского языка (НКРЯ), [в:] электронный ресурс: www.ruscorpora.ru (20.08.2015).

Р о м а н о в П.В., Я р с к а я - С м и р н о в а Е.Р., „Антропологический форум”, Санкт-Петербург 2007, № 7, с. 86.

С е р г е е ч е в а В., Словесное каратэ. Стратегия и тактика общения, Санкт-Петербург 2002.

Справочно-информационный портал Грамота.ру (ГР), [в:] электронный ресурс: http://gramota.ru/ (20.08.2015).

Электронный ресурс: http://news.tut.by/health/345002.html (08.05.2014).

B o r y ś W., Stownik etymologiczny języka polskiego, Kraków 2005.

Korpus Języka Polskiego Wydawnictwa Naukowego PWN (KJP), [в:] электронный ресурс: http://korpus.pwn.pl (18.08.2015).

S a r t o r i G., Homo videns. Telewizja i postmyślenie, Warszawa 2007.

Stownik wspótczesnego jezzyka polskiego (SWJP), red. B. Dunaj, Warszawa 1996.

Sposoby widzenia. Na podstawie cyklu programów telewizyjnych BBC Johna Bergera, Poznań 1997.

T i s s e $\mathrm{r}$ о $\mathrm{n}$ S., Dziecko w świecie obrazów, 2006, [в:] электронный ресурс: http://www.civilia.pl/art,112,moc-obrazu-wedlug-sergei-39-a-tisserona (02.07.2015).

Uniwersalny stownik jezzyka polskiego (USJP), red. S. Dubisz, [CD-ROM] wersja 1.0, 2004, Wydawnictwo Naukowe PWN, Warszawa. 